\title{
PENGEMBANGAN KAWASAN KAMPUNG PELANGI SEMARANG: PERSEPSI DAN DUKUNGAN MASYARAKAT
}

\author{
Aurilia Triani Aryaningtyas \\ Sekolah Tinggi Ilmu Ekonomi Pariwisata Indonesia (STIEPARI) Semarang \\ Email: aurilia.ta@gmail.com \\ Renny Aprilliyani \\ Sekolah Tinggi Ilmu Ekonomi Pariwisata Indonesia (STIEPARI) Semarang \\ Email: aprilliyanirenny@gmail.com \\ Hartoyo Soehari \\ Sekolah Tinggi Ilmu Ekonomi Pariwisata Indonesia (STIEPARI) Semarang \\ Email: hartoyosoehari@yahoo.co.id
}

\begin{abstract}
This study attempts to make a little contribution to the sustainable development of tourism by examining the residents' perceptions and support on the impact of the development of the Rainbow Village area as a tourist attraction in Semarang. Data were collected by means of a questionnaire. Based on 100 respondents surveyed, the findings show that the majority of respondents were male, aged between 36-45 years, were a native, who were born and lived in Wonosari village for more than 15 years. Overall, respondents viewed tourism positively and would support this development, because they consider the development of rainbow Village to contribute economically as well as socio-culture in Kampung Wonosari Semarang. They were generally in favor of development of rainbow Village that contributes economically and socio-culturally to Wonosari village. They were, however, slightly ambivalent to environmental impacts of tourism. Implications, policy recommendations and limitations of study are presented in the conclusion.
\end{abstract}

Keywords: perception, support, residents, development, rainbow village

\section{Pendahuluan}

Kota Semarang merupakan wilayah yang terletak di Provinsi Jawa Tengah yang dulunya merupakan kota perdagangan dan jasa. Kini Kota Semarang bertransformasi menjadi kota pariwisata yang memiliki beraneka ragam obyek wisata 
yang menarik untuk dikunjungi. Hal ini dapat dilihat dari berbagai destinasi lokasi wisata baru yang terus tumbuh di Kota Semarang (jateng.tribunnews.com, 2018).

Salah satu daerah di Kota Semarang yang sedang melakukan pengembangan pariwisata yaitu Kampung Gunung Brintik. Dulu kampung ini masuk kategori kawasan permukiman penduduk yang tergolong kumuh. Pemerintah Kota Semarang telah menyulap kampung Brintik menjadi kampung tematik yang disebut dengan Kampung Pelangi yang merupakan kawasan penuh warna-warni.

Dibentuknya kampung tematik bertujuan untuk mempercantik kampung yang dulunya tidak dikenal menjadi unik dan mampu menarik wisatawan untuk berkunjung sehingga dapat meningkatkan kesejahteraan masyarakatnya. Kampung yang penuh dengan cat warna-warni itu kini telah berubah menjadi kampung baru yang didesain khusus oleh seluruh stakeholder kota Semarang dan masyarakat sekitar. Saat ini, meskipun pengembangan masih terus dilakukan, kampung tersebut telah menjadi destinasi wisata nasional dan internasional. Penduduk lokal di Jawa Tengah dan masyarakat Indonesia pada umumnya patut bangga memiliki kampung baru yang kini sedang viral dan mendunia (jateng.tribunnews.com, 2018). Kampung Pelangi kini mulai dikembangkan dan dipublikasikan secara umum sebagai daya tarik wisata.

Peran pariwisata sangat penting dalam pengembangan perekonomian kota dan dalam memberikan manfaat bagi masyarakat setempat. Pengembangan pariwisata juga telah berdampak pada masyarakat dalam banyak hal, seperti: mengalami kemacetan lalu lintas, meningkatnya kejahatan, masalah kebersihan/ limbah dan meningkatnya biaya hidup (Nunkoo dan Ramkissoon, 2009). Industri pariwisata berkelanjutan didasarkan pada sejumlah faktor, Beberapa pertimbangan harus diberikan terkait dengan dampaknya terhadap masyarakat sekitar (Cahndralal, 2010). 
Pada umumnya masyarakat yang akan merasakan dan melihat pengembangan pariwisata yang ada didaerahnya, namun tidak semua pendapat masyarakat mengatakan baik atau buruk mengenai pengembangan pariwisata, karena setiap individu memiliki persepsi atau pandangan yang berbeda (Ginting dkk, 2017). Masyarakat yang mendapat manfaat positif akan lebih mendukung pengembangan pariwisata dan menerima kedatangan wisatawan dengan baik (Snaith dan Haley, 1999). Oleh karena itu sangat penting mengetahui persepsi masyarakat setempat terhadap pengembangan pariwisata agar dapat memperoleh dukungan yang lebih baik.

Selama dekade terakhir, perhatian akademis pada persepsi masyarakat terhadap dampak pariwisata semakin meningkat. Beberapa studi mengenai persepsi masyarakat terhadap pengembangan pariwisata telah dilakukan dari konteks pariwisata negara maju, maupun dari perspektif negara berkembang (Eshliki \& Kaboudi, 2012; Pham, 2012; Manalu et al, 2013; Saygin et al, 2015; Głąbiński \& Duda, 2017). Beberapa studi lain juga sudah meneliti mengenai dampak keberadaan kampung wisata (Hastuti \& Ismayanti, 2018; Wuri, dkk, 2015; Wulandari \& Luthfi, 2019). Namun menurut pengamatan peneliti, belum ada penelitian mengenai persepsi masyarakat terhadap dampak pengembangan kawasan Kampung Pelangi serta sebagai daya tarik wisata di Kampung Wonosari Kota Semarang. Berdasarkan hal tersebut di atas, maka peneliti tertarik untuk mengangkat topik mengenai Persepsi dan Dukungan Masyarakat terhadap Pengembangan Kawasan Kampung Pelangi sebagai Daya Tarik Wisata di Kampung Wonosari Kota Semarang.

\section{Kerangka Pikir}

\section{Konsep Pariwisata}

Pariwisata menurut World Tourism Organization (WTO) didefinisikan sebagai kegiatan seseorang yang bepergian ke atau tinggal di suatau tempat di luar 
lingkungannya yang biasa dalam waktu tidak lebih dari satu tahun secara terusmenerus, untuk kesenangan, bisnis ataupun tujuan lainnya (Pitana \& Diarta, 2009). Menurut Undang-undang No.10 Tahun 2009 tentang kepariwisataan, pariwisata merupakan berbagai macam kegiatan wisata dan didukung berbagai fasilitas serta layanan yang disediakan oleh masyarakat, pengusaha, pemerintah, dan pemerintah daerah.

Pariwisata mengandung tiga unsur antara lain: manusia, yaitu unsur insani sebagai pelaku kegiatan pariwisata; tempat, yaitu unsur fisik yang sebenarnya tercakup oleh kegiatan itu sendiri; dan waktu, yaitu tempo yang dihabiskan dalam perjalanan tersebut dan selama berdiam di tempat tujuan. Jadi, definisi pariwisata adalah salah satu dari industri baru yang mampu meningkatkan pertumbuhan ekonomi dengan cepat dalam hal kesempatan kerja, pendapatan, taraf hidup dan dalam hal mengaktifkan sektor produksi lain di dalam negara penerima wisatawan (Utama et al, 2017).

Pariwisata juga dapat dikatakan sebagai salah satu mesin penggerak perekonomian dunia karena sudah terbukti mampu memberikan kontribusi terhadap kemakmuran sebuah negara. Pembangunan pariwisata mampu membuat aktivitas bisnis semakin bergairah serta menghasilkan manfaat sosial, budaya, dan ekonomi yang signifikan bagi suatu Negara.

\section{Dampak Pengembangan Pariwisata}

Menurut Faizun (2009), dampak pariwisata adalah perubahan-perubahan yang terjadi terhadap masyarakat sebagai komponen dalam lingkungan hidup sebelum ada kegiatan pariwisata dan sesudah ada kegiatan pariwisata. Dampak pengembangan pariwisata telah terbukti mampu memperbaiki kualitas hidup masyarakat (Tibuludji et al, 2017). 
Berdasarkan perspektif ekonomi, pariwisata mempunyai dampak positif (Positive impact) bagi perekonomian regional dan nasional, antara lain : mendatangkan devisa, pasar potensial bagi produk barang dan jasa masyarakat setempat, meningkatkan pendapatan masyarakat yang kegiatannya terkait langsung atau tidak langsung dengan jasa pariwisata, memperluas penciptaan kesempatan kerja, sumber pendapatan asli daerah (PAD), serta merangsang kreativitas seniman sebagai konsumsi wisatawan (Utama et al, 2017).

Selain dampak yang positif, pariwisata dapat juga menimbulkan dampak yang negatif (negative impact) antara lain: menyusutnya lahan pertanian untuk pembangunan pendukung infrastruktur pariwisata, meningkatnya kriminalitas, kepadatan lalu lintas, urbanisasi dan emigrasi, bermunculan ruko-ruko (shopping center) yang melanggar tata ruang wilayah, degradasi lingkungan dan polusi.

Gursoy \& Denney (2004) juga mengemukakan bahwa perkembangan pariwisata dapat membawa dampak pada destinasi seperti dampak ekonomi, dampak sosial, budaya, dan lingkungan. Dampak ekonomi meliputi pekerjaan, investasi asing, peluang bisnis dan pendapatan pajak untuk pemerintah setempat. Dampak sosial terkait dari pengembangan pariwisata antara lain kenaikan tingkat harga, tingkat kejahatan, kemacetan lalu lintas, polusi dan lain-lain. Dampak sosial yang dirasakan antara lain penyediaan insentif untuk pelestarian budaya lokal, lebih banyak taman dan area rekreasi lainnya untuk penduduk setempat, insentif untuk pemulihan bangunan bersejarah, dan meningkatkan standar jalan dan fasilitas umum lainnya. Pariwisata juga akan membantu melestarikan budaya lokal melalui pengembangan kegiatan budaya oleh penduduk lokal yang menargetkan wisatawan, pertukaran budaya antara wisatawan dan penduduk setempat, dampak positif pada identitas budaya namun juga dapat mencemari budaya tuan rumah melalui berbagai cara. 


\section{Konsep Daya Tarik Wisata}

Daya tarik wisata menurut UU Republik Indonesia No. 10 Tahun 2009, dijelaskan sebagai segala sesuatu yang memiliki keunikan, kemudahan dan nilai-nilai yang berupa keanekaragaman, kekayaan alam, budaya dan hasil buatan manusia yang menjadi sasaran atau kunjungan wisatawan. Konsep lain mengemukakan daya tarik wisata sebagai suatu tempat atau daerah yang memiliki daya tarik bagi kunjungan wisatawan. Daya tarik tersebut berupa keadaan alam, flora, fauna, seni, dan budaya yang merupakan ciptaan TuhanYang Maha Esa (Hariyana \& Mahagangga, 2015).

Menurut Subhiksu \& Utama (2018) daya tarik wisata dapat dikelompokkan menjadi dua, yakni daya tarik wisata alamiah dan daya tarik wisata buatan. Daya tarik wisata alamiah adalah daya tarik wisata Ciptaan Tuhan Yang Maha Esa yang terdiri dari keadaan alam, flora, dan fauna. Sedangkan daya tarik wisata buatan merupakan hasil karya manusia yang terdiri dari museum, peninggalan sejarah, seni, dan budaya, wisata agro, wisata buru, wisata petualangan alam, taman rekreasi, dan komplek hiburan. Daya tarik wisata lainnya yakni minat khusus yang merupakan suatu hal yang menjadi daya tarik sesuai dengan minat dari wisatawannya seperti berburu, mendaki gunung, menyusuri gua, industri dan kerajinan, tempat perbelanjaan, sungai air deras, tempat-tempat ibadah, tempat ziarah, dan lainnya. Suatu daya tarik wisata, dapat secara langsung maupun tidak langsung mengubah kehidupan masyarakat pemilik destinasi kearah yang lebih baik (Sudarmayasa \& Nala, 2019).

\section{Kampung Wisata}

Kampung wisata merupakan suatu wilayah dimana sekelompok kecil wisatawan tinggal dalam atau dekat dengan suasana tradisional dan belajar tentang kehidupan kampung dan lingkungan setempat (Inskeep, 1991). Terdapat beberapa 
tipe wisatawan yang mengunjungi kampung wisata yaitu wisatawan domestik dan wisatawan manca negara.

Wuri, dkk (2015) mengemukakan bahwa keberadaan kampung wisata dapat membuka kesempatan kerja dan meningkatkan pendapatan warga masyarakatnya. Di samping itu keberadaannya juga membuat warga dapat memenuhi kebutuhan hidup sehari-hari, kebutuhan gizi, sandang, papan, perabotan rumah tangga, biaya pengobatan, serta mampu memenuhi kebutuhan biaya sekolah. Dengan demikian keberadaan kampung wisata cukup berperan dalam menggerakkan perekonomian masyarakatnya karena memberikan efek multiplier yang cukup besar dengan munculnya berbagai jenis usaha pendukung pariwisata serta dapat meningkatkan penghasilan masyarakat terutama dimasa ramainya kunjungan wisatawan.

\section{Persepsi Masyarakat}

Persepsi merupakan kesan yang diperoleh individu melalui panca indera kemudian di analisa (diorganisir), diintepretasi dan kemudian dievaluasi, sehingga individu tersebut memperoleh makna. Kesan tersebut bisa tunggal ataupun jamak, tergantung objek persepsi yang diamati (Robbins, 2003). Persepsi juga dapat didefinisikan sebagai pengalaman tentang objek, peristiwa, hubungan-hubungan yang diperoleh dengan menyimpulkan informasi dan menafsirkan pesan (Hariyana \& Mahagangga, 2015).

Menurut Toha (2003), faktor-faktor yang mempengaruhi persepsi seseorang adalah sebagai berikut: (a) Faktor internal, yaitu perasaan, sikap dan kepribadian individu, prasangka, keinginan atau harapan, perhatian (fokus), proses belajar, keadaan fisik, gangguan kejiwaan, nilai dan kebutuhan juga minat, dan motivasi. (b) Faktor eksternal, yaitu latar belakang keluarga, informasi yang diperoleh, pengetahuan dan kebutuhan sekitar, intensitas, ukuran, keberlawanan, pengulangan gerak, hal-hal baru dan familiar atau ketidakasingan suatu objek. 
Masyarakat adalah suatu kesatuan hidup manusia yang berinteraksi menurut suatu adat istiadat tertentu yang bersifat kontinyu, dan yang terikat oleh suatu rasa identitas bersama (Hariyana \& Mahagangga, 2015). Jadi persepsi masyarakat dapat didefinisikan sebagai proses penilaian seseorang/sekelompok orang terhadap objek, peristiwa, atau stimulus dengan melibatkan pengalaman-pengalaman yang berkaitan dengan objek tersebut, melalui proses kognisi dan afeksi untuk membentuk objek tersebut. Dalam industri pariwisata, masyarakat lokal merupakan salah satu pemangku kepentingan utama. Oleh karena itu, dalam teori organisasi disarankan agar lembaga-lembaga yang terkait dengan pariwisata harus berinteraksi dengan masyarakat serta mendengarkan pendapat masyarakat tentang masalah dan program pariwisata untuk mendapatkan dukungan mereka (Sharma et.al, 2008).

\section{Dukungan Masyarakat}

Teori pertukaran sosial (social exchange theory) telah menjadi kerangka kerja yang paling umum diterima di Indonesia untuk menjelaskan reaksi masyarakat terhadap pengembangan pariwisata, karena memungkinkan untuk memperoleh pandangan yang berbeda berdasarkan hasil pengalaman dan psikologis (Nunkoo \& Ramkissoon, 2011; Prayag et al., 2013). Teori pertukaran sosial menganggap interaksi sosial sebagai pertukaran sumber daya yang menunjukkan bahwa individu cenderung terlibat dalam pertukaran jika mereka mengharapkan memperoleh manfaat dari pertukaran tersebut tanpa menimbulkan biaya yang tidak diinginkan. Sehubungan dengan pariwisata, sikap masyarakat dibangun berdasarkan evaluasi yang mereka lakukan terhadap pariwisata "dalam hal manfaat yang diperoleh sebagai imbalan untuk layanan yang mereka berikan ataupun atau biaya yang harus dikeluarkan". Jika mereka merasakan dampak (manfaat) yang diperoleh lebih besar daripada potensi konsekuensi negatif (biaya), maka masyarakat cenderung mendukung pengembangan pariwisata (Dyer et al., 2007; Gursoy et al., 2010; Ko \& Stewart, 2002; Lee, 2013). Dengan demikian, persepsi masyarakat terhadap dampak pariwisata sangat penting sebagai pertimbangan bagi keberhasilan pengembangan 
dan pengoperasian pariwisata (Andriotis \& Vaughan, 2003; McGehee \& Andereck, 2004). Berdasarkan konsep-konsep yang telah diuraikan di atas, maka dapat dibuat kerangka pemikiran sebagai berikut:

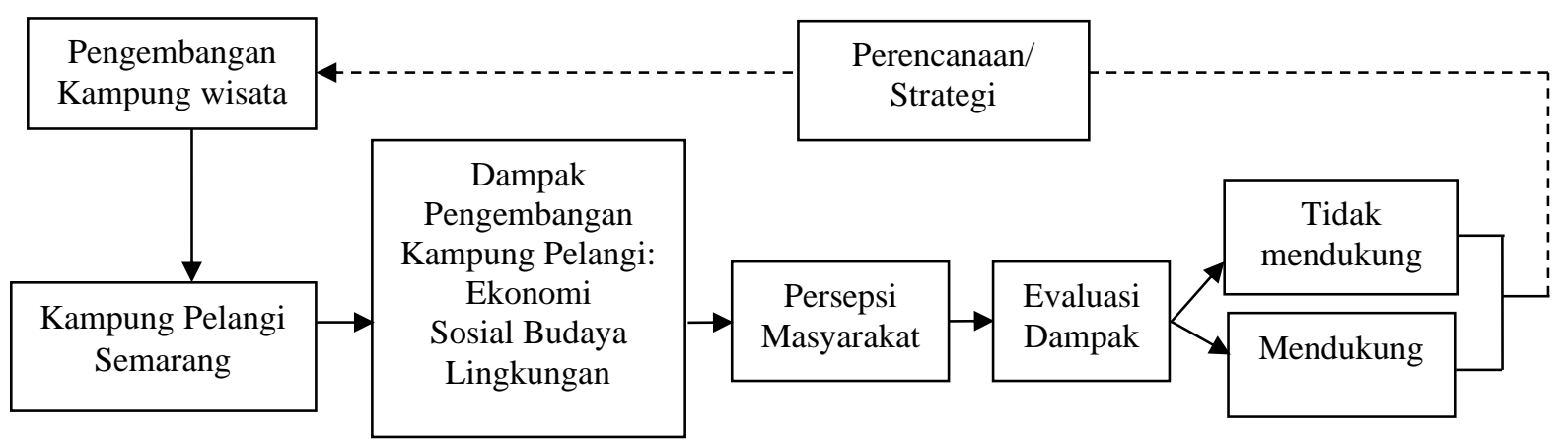

Gambar 1. Kerangka Pemikiran Teoretis

\section{Metode Penelitian}

Penelitian ini menggunakan pendekatan kuantitatif dan menekankan analisis pada data numerical yang diolah dengan menggunakan metode statistik. Jenis penelitian yang dipilih adalah penelitian deskriptif dimana penelitian ini hanya melakukan analisis sampai taraf deskripsi, yaitu menganalisis dan menyajikan data secara sistematik sehingga data lebih mudah untuk dipahami dan disimpulkan agar dapat menggambarkan fakta dan karakterisitik mengenai populasi secara sistematik dan akurat.

Penelitian ini bersifat eksploratif dan menggunakan statistik deskriptif untuk mengukur persepsi masyarakat tentang dampak pengembangan kawasan Kampung Pelangi sebagai daya tarik wisata di Kampung Wonosari Kota Semarang serta dukungan mereka terhadap pengembangan Kampung Pelangi.

Populasi dalam penelitian ini adalah masyarakat yang tinggal di kawasan Kampung Pelangi di kampung Wonosari Semarang yang berjumlah sekitar 700 keluarga. Teknik sampling yang digunakan adalah quota sampling, dimana peneliti menentukan sampel dari populasi yang mempunyai ciri-ciri tertentu sampai jumlah (kuota) yang diinginkan (Sugiyono, 2011). Dalam penelitian ini sampel diambil 
sebesar 100 orang dari 700 keluarga yang ada, sesuai dengan pernyataan Baley dalam Mahmud (2011) bahwa untuk penelitian yang menggunakan analisis data statistik, ukuran sampel minimum adalah 30. Pengumpulan data dalam penelitian ini dilakukan dengan penyebaran kuesioner terstruktur kepada 100 responden yang menjadi sampel. Metode pengambilan sampel menggunakan Purposive Sampling yaitu teknik pengambilan sampel dengan pertimbangan tertentu (Sugiyono, 2011). Pertimbangan yang digunakan adalah orang yang memiliki cukup pengetahuan dan pemahaman tentang pengembangan kawasan Kampung Pelangi di kampung Wonosari Semarang.

Data primer diperoleh dengan menyebarkan kuesioner kepada 100 orang yang mewakili masyarakat Kampung Pelangi. Setiap responden diminta memberikan tanggapan mengenai persepsi dan dukungannya terhadap pengembangan kawasan Kampung Pelangi sebagai daya tarik wisata di Kampung Wonosari Kota Semarang. Dalam penelitian ini, kuesioner dibagikan langsung pada responden sehingga peneliti dapat memberikan penjelasan mengenai tujuan survey dan pertanyaan yang kurang dipahami oleh responden. Tanggapan atas kuesioner langsung dikumpulkan oleh peneliti setelah diisi oleh responden. Kuesioner secara personal digunakan untuk mendapatkan data tentang dimensi-dimensi dari variabel yang sedang dikembangkan dalam penelitian ini.

Penelitian ini menggunakan dua variabel yaitu persepsi masyarakat dan dukungan masyarakat terhadap dampak pengembangan kawasan Kampung Pelangi sebagai daya tarik wisata di Kampung Wonosari Kota Semarang. Kuesioner yang digunakan dalam penelitian ini terdiri dari dua bagian. Bagian pertama bertujuan untuk mendapatkan informasi tentang variabel demografis responden seperti jenis kelamin, usia, status perkawinan, latar belakang pendidikan, dan pekerjaan. Di bagian kedua kuesioner, pertanyaan mengukur persepsi dan dukungan masyarakat setempat terhadap pengembangan Kampung Pelangi sebagai daya tarik wisata di Kampung Wonosari Kota Semarang. 
Kuesioner yang digunakan dalam penelitian ini disusun menggunakan pertanyaan yang telah diuji sebelumnya yang digunakan oleh Andriotis (2004); Chen dan Chen (2010); dan Pham (2012). Penelitian mereka mengenai persepsi penduduk terhadap dampak pariwisata dan pengembangan pariwisata digunakan sebagai model dalam penelitian ini. Namun, karena pertanyaan dalam penelitian tersebut dikembangkan dalam kondisi yang berbeda dengan lokasi penelitian ini, pernyataan tersebut diadaptasi sesuai dengan kondisi di Kampung Pelangi Semarang, dengan mempertimbangkan budaya, geografi, lingkungan, dan dinamika pengembangan pariwisata yang ada di daerah tersebut, sehingga ada beberapa pertanyaan yang tidak digunakan dalam penelitian ini.

Bagian pertama terdiri dari 7 kuesioner yang berkaitan dengan karakteristik sosio-demografis masyarakat tanpa mencantumkan nama untuk menjaga privasi responden. Bagian kedua kuesioner terdiri dari 26 item pernyataan, mencakup tiga hal yaitu: (1) Delapan belas item pernyataan dimaksudkan untuk mengukur persepsi masyarakat terhadap dampak pengembangan Kampung Pelangi sebagai daya tarik wisata di Kampung Wonosari Kota Semarang. (2) Dua item pernyataan untuk mengukur evaluasi/ penilaian keseluruhan dampak pengembangan Kampung Pelangi oleh masyarakat, dan (3) Enam item pernyataan untuk mengukur dukungan masyarakat terhadap pengembangan Kampung Pelangi sebagai daya tarik wisata di Kampung Wonosari Kota Semarang. Skala Likert lima poin digunakan untuk mengukur pendapat responden $(1$ = sangat tidak setuju, 2 = tidak setuju, $3=$ kurang setuju, 4 = setuju, dan 5 = sangat setuju).

Pertanyaan terakhir meminta responden untuk memberikan komentar tambahan yang ingin disampaikan terkait pengembangan Kampung Pelangi sebagai daya tarik wisata di Kampung Wonosari Kota Semarang. Seluruh kuesioner ini dirancang untuk menguji studi yang luas tentang persepsi masyarakat terhadap dampak pengembangan Kampung Pelangi di Kampung Wonosari Semarang. 


\section{Hasil dan Pembahasan}

\section{Profil Responden}

Tabel 1. Karakteristik Sosio-Demografis Masyarakat

\begin{tabular}{|c|c|c|}
\hline Variabel Demografi & Frekuensi & Persentase \\
\hline \multicolumn{3}{|l|}{ Jenis Kelamin } \\
\hline Laki-laki & 83 & 83,00 \\
\hline Perempuan & 17 & 17,00 \\
\hline \multicolumn{3}{|l|}{ Usia } \\
\hline 18-25 tahun & 15 & 15,00 \\
\hline 26-35 tahun & 25 & 25,00 \\
\hline 36-45 tahun & 37 & 37,00 \\
\hline$>45$ tahun & 23 & 23,00 \\
\hline \multicolumn{3}{|l|}{ Tempat lahir } \\
\hline Kampung Wonosari & 57 & 57,00 \\
\hline Lainnya & 43 & 43,00 \\
\hline \multicolumn{3}{|l|}{ Pendidikan } \\
\hline Lulus SD/sederajat & 15 & 15,00 \\
\hline Lulus SMP/sederajat & 17 & 17,00 \\
\hline Lulus SMA/sederajat & 58 & 58,00 \\
\hline Lulus Perguruan Tinggi & 10 & 10,00 \\
\hline \multicolumn{3}{|l|}{ Penghasilan/ bulan } \\
\hline$<\operatorname{Rp} 1.000 .000$ & 13 & 13,00 \\
\hline Rp 1.000.000 - 2.000.000 & 25 & 25,00 \\
\hline Rp 2.000.001 - 3.000.000 & 35 & 35,00 \\
\hline Rp 3.000.001-4.000.000 & 17 & 17,00 \\
\hline$>\operatorname{Rp} 4.000 .000$ & 10 & 10,00 \\
\hline \multicolumn{3}{|l|}{ Status Pekerjaan } \\
\hline Terkait pariwisata & 34 & 34,00 \\
\hline Tidak terkait pariwisata & 66 & 66,00 \\
\hline \multicolumn{3}{|c|}{ Lama Tinggal di Kampung Wonosari } \\
\hline$<1$ tahun & 2 & 2,00 \\
\hline $1-5$ tahun & 4 & 4,00 \\
\hline $6-10$ tahun & 11 & 11,00 \\
\hline $11-15$ tahun & 22 & 22,00 \\
\hline$>15$ tahun & 61 & 61,00 \\
\hline
\end{tabular}

Sumber: Data primer, diolah. 
Dari tabel 1 terlihat bahwa responden didominasi oleh laki-laki (83\%), berusia antara 36-45 tahun, dan lahir di Kampung Wonosari (57\%). Dalam hal tingkat pendidikan, terdapat konsentrasi di tingkat SMA/sederajat (58\%). Pendapatan mayoritas responden 35\% berada di antara 2-3 juta rupiah. Terkait status pekerjaan, $66 \%$ responden menyatakan bahwa pekerjaan mereka tidak terkait dengan industri pariwisata, sedangkan $34 \%$ terkait pariwisata. Periode lama tinggal yang paling sering dilaporkan adalah lebih dari 15 tahun (61\% responden).

\section{Persepsi Masyarakat terhadap Dampak Pengembangan Kampung Pelangi}

\section{a. Dampak Ekonomi}

Tabel 2. Persepsi Masyarakat terhadap Dampak Ekonomi Pengembangan Kampung Pelangi

\begin{tabular}{|c|c|c|c|}
\hline Peringkata) & Pernyataan & $\begin{array}{l}\text { Rata- } \\
\text { rata }^{\text {b) }}\end{array}$ & $\begin{array}{l}\text { Persentase } \\
\text { Setuju }^{c}\end{array}$ \\
\hline 1 & $\begin{array}{l}\text { Pengembangan Kampung Pelangi menciptakan } \\
\text { peluang bisnis baru bagi penduduk setempat }\end{array}$ & 4.74 & 92.00 \\
\hline 2 & $\begin{array}{l}\text { Pengembangan Kampung Pelangi telah } \\
\text { meningkatkan peluang kerja di Kampung Wonosari } \\
\text { Semarang }\end{array}$ & 4.42 & 91.00 \\
\hline 3 & $\begin{array}{l}\text { Standar hidup masyarakat meningkat pesat karena } \\
\text { pengembangan Kampung Pelangi }\end{array}$ & 4.20 & 87.00 \\
\hline 4 & $\begin{array}{l}\text { Pengembangan Kampung Pelangi merupakan salah } \\
\text { satu hal penting yang mendukung ekonomi lokal }\end{array}$ & 4.12 & 78.00 \\
\hline 5 & $\begin{array}{l}\text { Harga banyak barang dan jasa di Kampung } \\
\text { Wonosari telah meningkat karena pengembangan } \\
\text { Kampung Pelangi }\end{array}$ & 3.85 & 75.00 \\
\hline 6 & $\begin{array}{l}\text { Harga tanah dan bangunan di Kampung Wonosari } \\
\text { meningkat karena pengembangan Kampung Pelangi }\end{array}$ & 3.84 & 71.00 \\
\hline 7 & $\begin{array}{l}\text { Kualitas layanan publik di Kampung Wonosari } \\
\text { sekarang lebih baik }\end{array}$ & 3.78 & 68.0 \\
\hline & Rata-rata & 4.14 & 80.29 \\
\hline
\end{tabular}

a) Pertanyaan diberi peringkat berdasarkan skor rata-rata; ${ }^{\text {b) }}$ rentang skala dari 1 = sangat tidak setuju sampai 5 = sangat setuju; ${ }^{c)}$ persentase setuju adalah mereka yang menjawab 4 dan 5 pada skala 5 poin. 
Dari hasil tersebut dapat disimpulkan bahwa tujuh item pernyataan mendapatkan skor dengan kategori tinggi yaitu rata-rata 4,14 dan persentase persetujuan responden rata-rata $80,29 \%$. Ini berarti hanya tidak banyak responden yang merasakan bahwa pengembangan Kampung Pelangi telah mengganggu kegiatan ekonomi mereka sehari-hari. Tidak mengherankan karena pariwisata dianggap mempunyai peran vital dalam perekonomian lokal.

Hal di atas juga menunjukkan bahwa masyarakat sangat menghargai manfaat yang diperoleh dari pengembangan Kampung Wonosari menjadi kampung tematik yang berwarna-warni atau yang disebut sebagai Kampung Pelangi. Responden di Kampung Wonosari menaruh harapan besar dan cenderung memiliki sikap positif terhadap kesuksesan pengembangan Kampung Pelangi.

Ada kesepakatan yang kuat dari responden mengenai manfaat ekonomi pengembangan Kampung Pelangi bagi perekonomian kampung Wonosari Semarang karena dampak positif yang paling dirasakan yaitu banyaknya pengunjung yang datang ternyata dapat menciptakan peluang bisnis baru bagi penduduk setempat dan mampu meningkatkan peluang pekerjaan di kampung Wonosari Semarang. Pada awal pengembangan Kampung Pelangi, banyak warga yang tidak memiliki pekerjaan tetap dan mereka membuka toko atau warung di Kampung Pelangi. Salah satu warga yang merupakan ibu rumah tangga menyatakan bahwa sebelumnya hanya mengandalakan gaji dari suami untuk mencukupi kebutuhan hidup, tapi setelah dikembangkannya Kampung Pelangi, dia membuka warung yang menjajakan makanan dan minuman kepada wisatawan, sehingga mampu memperoleh penghasilan tambahan untuk membantu perekonomian keluarga. Warga lain, yang merupakan penjual soto di Kampung Pelangi juga mengatakan setelah diresmikannya Kampung Pelangi, pendapatannya meningkat hingga lebih dari 50\%. Hal ini karena sejak Kampung Pelangi diresmikan, banyak wisatawan baik lokal maupun mancanegara yang berkunjung ke sana. 
Sesuai dengan yang dikemukakan oleh Wuri, dkk. (2015) bahwa keberadaan kampung wisata dapat membuka kesempatan kerja dan sangat berperan dalam menggerakkan perekonomian masyarakatnya karena memberikan efek multiplier yang cukup besar dengan munculnya berbagai jenis usaha pendukung pariwisata sehingga dapat meningkatkan penghasilan masyarakat terutama dimasa ramainya kunjungan wisatawan.

Akibat dari adanya kegiatan pariwisata tersebut, UKM di kampung tersebut juga tumbuh dan berkembang. Berbagai kreasi UKM berupa makanan dan minuman, maupun cenderamata seperti kaos, gantungan kunci, dan sebagainya menjadi hidup. Masyarakat sekitar yang sebelumnya tidak memiliki mata pencaharian mulai merasakan dampaknya. Pembuatan kerajinan tangan yang dapat dijual kepada wisatawan telah menjadi sebuah proses pendayagunaan masyarakat di skala perekonomian daerah yang diharapkan dapat meningkatkan kesejahteraan masyarakat. Hal ini sesuai dengan teori yang menyatakan bahwa berdasarkan perspektif ekonomi, pariwisata mempunyai dampak positif (Positive impact) bagi perekonomian regional dan nasional (Utama et al, 2017). Secara ekonomi pariwisata berdampak positif pada perekonomian masyarakat setempat, seperti memberikan peluang kerja dan pertumbuhan ekonomi (Pham, 2012). Dengan demikian pengembangan Kampung Pelangi diharapkan mampu meningkatkan standar hidup masyarakat dan sekaligus mampu mendukung ekonomi daerah setempat. Hal ini dapat menjadi poin utama yang menjadi dasar dalam menindaklanjuti program pengembangan Kampung Pelangi.

Setelah melewati tahun 2017, meski secara riil pasti ada wisatawan yang datang setiap harinya, namun jumlah pengunjung Kampung Pelangi semakin menurun dari tahun ke tahun. Berbagai kegiatan sudah dilakukan, baik oleh Pemerintah Kota Semarang maupun berbagai komunitas. Kegiatan itu antara lain menyelenggarakan Festival Kampung Pelangi dengan tujuan untuk menarik kembali 
wisatawan yang datang di Kelurahan Randusari, Kota Semarang, Jawa Tengah agar Kampung Pelangi yang mulai meredup dapat hidup kembali.

\section{b. Dampak Sosial Budaya}

Tabel 3. Persepsi Masyarakat terhadap Dampak Sosial Budaya Pengembangan Kampung Pelangi

\begin{tabular}{|c|c|c|c|}
\hline Peringkata) & Pernyataan & $\begin{array}{l}\text { Rata- } \\
\text { rata }^{\text {b) }}\end{array}$ & $\begin{array}{l}\text { Persentase } \\
\text { Setuju }^{c)}\end{array}$ \\
\hline 1 & $\begin{array}{l}\text { Pengembangan Kampung Pelangi telah } \\
\text { meningkatkan kualitas hidup penduduk secara } \\
\text { keseluruhan }\end{array}$ & 4.75 & 93.00 \\
\hline 2 & $\begin{array}{l}\text { Karena pengembangan Kampung Pelangi, } \\
\text { masyarakat setempat kini memiliki lebih } \\
\text { banyak peluang rekreasi }\end{array}$ & 4.71 & 91.00 \\
\hline 3 & $\begin{array}{l}\text { Pengembangan Kampung Pelangi mendorong } \\
\text { berbagai kegiatan budaya seperti kerajinan, } \\
\text { seni, di kampung Wonosari Semarang }\end{array}$ & 4.39 & 88.00 \\
\hline 4 & $\begin{array}{l}\text { Pengembangan Kampung Pelangi telah } \\
\text { meningkatkan kebanggaan penduduk } \\
\text { terhadap budaya lokal }\end{array}$ & 4.11 & 85.00 \\
\hline 5 & $\begin{array}{l}\text { Pengembangan Kampung Pelangi telah } \\
\text { menghasilkan pertukaran budaya yang lebih } \\
\text { besar antara wisatawan dan penduduk }\end{array}$ & 4.08 & 75.00 \\
\hline 6 & $\begin{array}{l}\text { Pengembangan Kampung Pelangi telah } \\
\text { membantu melestarikan identitas budaya } \\
\text { penduduk setempat }\end{array}$ & 3.98 & 73.00 \\
\hline \multirow[t]{2}{*}{7} & $\begin{array}{l}\text { Pengembangan Kampung Pelangi telah } \\
\text { meningkatkan kualitas produk dan layanan } \\
\text { infrastruktur pariwisata seperti jalan, sistem } \\
\text { transportasi, restoran, toko, dan wisma di } \\
\text { daerah tersebut }\end{array}$ & 3.60 & 47.00 \\
\hline & Rata-rata & 4.23 & 78.86 \\
\hline
\end{tabular}

a) Pertanyaan diberi peringkat berdasarkan skor rata-rata; ${ }^{\text {b) }}$ rentang skala dari 1 = sangat tidak

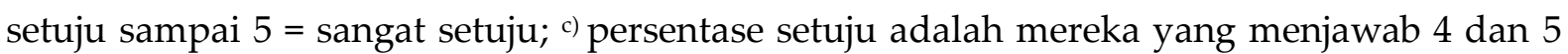
pada skala 5 poin. 
Secara keseluruhan, hasil pengolahan data tidak mengungkapkan kekhawatiran responden terhadap dampak negatif sosial budaya yang dirasakan sebagai akibat pengembagan kampung Wonosari sebagai Kampung Pelangi/ kampung tematik. Temuan mengenai persepsi terhadap dampak sosial budaya menunjukkan bahwa pengembangan Kampung Pelangi Semarang juga telah mampu meningkatkan kualitas hidup penduduk. Pengembangan Kampung Pelangi mendorong masyarakat untuk berperan dalam menjaga kualitas perumahan dan infrastrukturnya. Peningkatan kualitas permukiman dikembangkan guna mendukung pariwisata Kampung Pelangi agar dapat meningkatkan kualitas objek wisata. Pada akhirnya wisatawan akan lebih mudah untuk berkunjung, dan dapat meningkatkan pendapatan masyarakat melalui kegiatan pariwisata.

Masyarakat setempat saat ini merasa memiliki peluang rekreasi lebih banyak dengan dikembangkannya kampung Wonosari sebagai Kampung Pelangi. Pemukiman yang dulunya kumuh telah berubah menjadi tempat yang menarik dan dapat dinikmati oleh warga sebagai tempat rekreasi. Selain itu kedatangan wisatawan dapat menjadi hiburan bagi penduduk setempat untuk melepas kejenuhan.

Gursoy \& Denney (2004) mengemukakan bahwa perkembangan pariwisata dapat membawa dampak pada destinasi. Kegiatan pariwisata akan membantu melestarikan budaya lokal melalui pengembangan kegiatan budaya oleh penduduk lokal yang menargetkan wisatawan. Masyarakat dapat merasakan bahwa berbagai kegiatan budaya seperti kerajinan dan seni di kampung Wonosari Semarang menjadi berkembang sejak dikembangkannya kampung Wonosari sebagai Kampung Pelangi. Grup jathilan merupakan salah satu kesenian yang dikembangkan di kampung ini. Meski demikian, masih diharapkan adanya pendampingan mengenai pemasaran kerajinan warga maupun seni. 
Temuan lain menyatakan bahwa responden kurang begitu sepakat bahwa pengembangan Kampung Pelangi dapat meningkatkan kualitas produk dan layanan infrastruktur pariwisata seperti jalan, sistem transportasi, restoran, toko, dan wisma di daerah tersebut. Menurut pandangan masyarakat, peran pemerintah masih sangat penting dalam menyediakan infrastruktur guna mendukung pengembangan Kampung Pelangi di Kampung Wonosari. Beberapa kekurangan yang masih ada di Kampung ini antara lain MCK yang kurang memadai, infrastruktur jalan juga belum memadai (jalan-jalan yang masih sempit, hanya mempunyai lebar kurang dari 2 meter, sehingga tidak bisa dilewati oleh kendaraan roda 4 , dan pada jalan - jalan tertentu sangat curam sehingga hanya dapat dilewati oleh pejalan kaki saja), akses keluar dan masuk yang belum ditata, dan yang paling penting adalah akses air karena posisi kampung ini berada di atas bukit. Selain itu, sebagai kampung wisata, infrastruktur yang ada masih kurang karena tidak ada tempat bermain. Oleh karena itu, Pemerintah Kota Semarang diharapkan dapat meningkatkan kualitas produk dan layanan infrastruktur pariwisata seperti jalan, sistem transportasi, restoran, toko, dan wisma di daerah tersebut agar dapat mendukung kegiatan pariwisata yang ada di Kampung Pelangi

\section{c. Dampak Lingkungan}

Tabel 4. Persepsi Masyarakat terhadap Dampak Lingkungan Pengembangan Kampung Pelangi

\begin{tabular}{clcc}
\hline Peringkat $^{\text {a) }}$ & \multicolumn{1}{c}{ Pernyataan } & $\begin{array}{c}\text { Rata- } \\
\text { rata }^{\text {b) }}\end{array}$ & $\begin{array}{c}\text { Persentase } \\
\text { Setuju }^{\text {c }}\end{array}$ \\
\hline 1 & $\begin{array}{l}\text { Pengembangan Kampung Pelangi telah } \\
\text { meningkatkan penampilan daerah (visual dan } \\
\text { estetika) }\end{array}$ & 4.79 & 92.00 \\
\hline 2 & $\begin{array}{l}\text { Pengembangan Kampung Pelangi memberikan } \\
\text { insentif untuk restorasi bangunan bersejarah. }\end{array}$ & 4.76 & 90.00 \\
\hline 3 & $\begin{array}{l}\text { Fasilitas pariwisata yang dibangun di dalam } \\
\text { dan sekitar Kampung Pelangi selaras dengan } \\
\text { lingkungan alam dan arsitektur tradisional }\end{array}$ & 4.13 & 87.00 \\
\hline
\end{tabular}




\begin{tabular}{llcc}
\hline 4 & $\begin{array}{l}\text { Pengembangan Kampung Pelangi tidak } \\
\text { menyebabkan kemacetan lalu lintas yang } \\
\text { signifikan, limbah padat, udara, dan air, } \\
\text { kebisingan, dan polusi tanah }\end{array}$ & 3.46 & 48.00 \\
\hline & Rata-rata & $\mathbf{4 , 2 9}$ & $\mathbf{7 9 , 2 5}$ \\
\hline
\end{tabular}

a) Pertanyaan diberi peringkat berdasarkan skor rata-rata; ${ }^{\text {b) }}$ rentang skala dari 1 = sangat tidak setuju sampai 5 = sangat setuju; ${ }^{c}$ persentase setuju adalah mereka yang menjawab 4 dan 5 pada skala 5 poin.

Temuan mengenai persepsi terhadap dampak lingkungan menunjukkan pengembangan Kampung Pelangi telah mampu mengubah karakter warga menjadi yang cinta kebersihan dan keindahan. Terbukti dari berubahnya penampilan daerah yang tadinya kumuh kini menjadi lebih bersih dan representatif serta mampu mendatangkan banyak wisatawan untuk berkunjung ke daerah tersebut.

Satu hal yang mungkin masih menjadi kekhawatiran dari masyarakat adalah bahwa pengembangan Kampung Pelangi ini akan menyebabkan kemacetan lalu lintas yang signifikan, mengingat lokasinya yang berada di pusat kota serta terletak di pinggir jalan raya yang padat lalu lintas. Ada kekhawatiran juga dari masyarakat mengenai limbah padat, udara, dan air, kebisingan, dan polusi tanah yang dihasilkan dari aktivitas pariwisata yang semakin meningkat di kampung ini.

Meskipun demikian secara keseluruhan dapat disimpulkan bahwa empat item pernyataan mendapatkan skor dengan kategori tinggi yaitu rata-rata 4,29 dan persentase pertetujuan responden rata-rata 79,25\% yang berarti mayoritas masyarakat menyatakan setuju dengan dampak terhadap lingkungan yang lebih positif daripada negatif. 


\section{d. Evaluasi Keseluruhan Dampak Pengembangan Kampung Pelangi oleh}

\section{Masyarakat}

Dalam hal keseluruhan evaluasi dampak pengembangan Kampung Pelangi Semarang, 90\% responden sangat yakin bahwa manfaat pengembangan Kampung Pelangi lebih besar dibandingkan dengan biaya/kerugian yang ditimbulkan. Bahkan mereka juga percaya bahwa pengembangan Kampung Pelangi lebih banyak memberikan dampak positif dari pada dampak negatifnya ( $88 \%$ ). Hanya sejumlah kecil responden $(10 \%)$ yang kurang begitu yakin bahwa manfaat pengembangan Kampung Pelangi lebih besar dibandingkan dengan biaya/kerugian yang ditimbulkan, dan $12 \%$ yang kurang begitu yakin dengan dampak positif yang ditimbulkan.

Tabel 5. Evaluasi Keseluruhan Dampak Pengembangan Kampung Pelangi oleh Masyarakat

\begin{tabular}{clcc}
\hline Peringkat & \multicolumn{1}{c}{ Pernyataan } & $\begin{array}{c}\text { Rata- } \\
\text { rata }^{\text {b) }}\end{array}$ & $\begin{array}{c}\text { Persentase } \\
\text { Setuju }^{\text {c) }}\end{array}$ \\
\hline 1 & $\begin{array}{l}\text { Secara keseluruhan, masyarakat percaya } \\
\text { bahwa manfaat pengembangan Kampung } \\
\text { Pelangi lebih besar dibandingkan dengan } \\
\text { biaya/kerugian yang ditimbulkan. }\end{array}$ & 4.27 & 90.00 \\
\hline 2 & $\begin{array}{l}\text { Pengembangan Kampung Pelangi di } \\
\text { Kampung Wonosari Semarang menghasilkan } \\
\text { lebih banyak dampak positif dari pada } \\
\text { dampak negatifnya }\end{array}$ & 4.13 & 88.00 \\
\hline
\end{tabular}

$\begin{array}{llr}\text { Rata-rata } & 4.20 & 89.00\end{array}$

a) Pertanyaan diberi peringkat berdasarkan skor rata-rata; b) rentang skala dari 1 = sangat tidak setuju sampai 5 = sangat setuju; ${ }^{\text {c) }}$ persentase setuju adalah mereka yang menjawab 4 dan 5 pada skala 5 poin.

Dari tabel juga dapat dilihat bahwa skor rata-rata yang diperoleh dua item pernyataan adalah sebesar 4,20, tergolong dalam kategori tinggi dengan rata-rata persentase persetujuan responden mencapai $89,00 \%$. Mayoritas masyarakat percaya bahwa manfaat pengembangan Kampung Pelangi lebih besar dibandingkan dengan 
biaya/kerugian yang ditimbulkan. Bahkan mereka sangat yakin bahwa pengembangan Kampung Pelangi lebih banyak memberikan dampak positif dari pada dampak negatifnya.

\section{Dukungan Masyarakat terhadap Pengembangan Kampung Pelangi}

Tabel 6. Dukungan Masyarakat terhadap Pengembangan Kampung Pelangi

\begin{tabular}{|c|c|c|c|}
\hline Peringkata $^{a}$ & Pernyataan & $\begin{array}{l}\text { Rata- } \\
\text { ratab) }^{\text {b) }}\end{array}$ & $\begin{array}{l}\text { Persentase } \\
\text { Setuju }^{c}\end{array}$ \\
\hline 1 & $\begin{array}{l}\text { Masyarakat mendukung pengembangan } \\
\text { Kampung Pelangi karena memiliki peran } \\
\text { ekonomi yang vital di Kampung Wonosari } \\
\text { Semarang. }\end{array}$ & 4.67 & 93.00 \\
\hline 2 & $\begin{array}{l}\text { Masyarakat bersedia terlibat dalam } \\
\text { pengembangan Kampung Pelangi untuk } \\
\text { pariwisata berkelanjutan di masa depan. }\end{array}$ & 4.62 & 91.00 \\
\hline 3 & $\begin{array}{l}\text { Masyarakat sangat mendukung pengembangan } \\
\text { Kampung Pelangi di Kampung Wonosari } \\
\text { Semarang }\end{array}$ & 4.41 & 90.00 \\
\hline 4 & $\begin{array}{l}\text { Pemerintah harus meningkatkan upayanya } \\
\text { menyediakan infrastruktur guna mendukung } \\
\text { pengembangan Kampung Pelangi di Kampung } \\
\text { Wonosari Semarang }\end{array}$ & 4.16 & 88.00 \\
\hline 5 & $\begin{array}{l}\text { Masyarakat bersedia menjadi bagian dari } \\
\text { perencanaan pariwisata untuk Kampung Pelangi } \\
\text { di masa depan. }\end{array}$ & 4.08 & 85.00 \\
\hline \multirow[t]{2}{*}{6} & $\begin{array}{l}\text { Masyarakat ingin melihat lebih banyak turis di } \\
\text { Kampung Pelangi }\end{array}$ & 3.91 & 75.00 \\
\hline & Rata-rata & 4.31 & 87.00 \\
\hline
\end{tabular}

a) Pertanyaan diberi peringkat berdasarkan skor rata-rata; ${ }^{\text {b) }}$ rentang skala dari 1 = sangat tidak setuju sampai 5 = sangat setuju; ${ }^{c)}$ persentase setuju adalah mereka yang menjawab 4 dan 5 pada skala 5 poin.

Hasil temuan menunjukkan dukungan positif masyarakat terhadap pengembangan Kampung Pelangi dalam kategori tinggi (skor rata-rata 4,31). Hal ini tentunya tidak mengejutkan, karena dapat dijelaskan dengan teori pertukaran sosial yang mengasumsikan bahwa potensi hasil yang bermanfaat akan menciptakan sikap 
positif terhadap pariwisata, sehingga temuan ini mendukung hasil penelitian dari Dyer et al. (2007), Gursoy et al. (2010), Ko \& Stewart (2002), dan Lee (2013).

Dukungan positif dari masyarakat dapat dilihat dari semangat mereka yang siap berbenah untuk tetap menjaga keindahan Kampung Pelangi agar tetap eksis di tengah pandemi Covid 19. Pada era adaptasi new normal, Kampung Pelangi tetap menerima kunjungan wisatawan, dengan catatan, protokol kesehatan harus tetap dijalankan secara ketat. Pengunjung diwajibkan untuk mencuci tangan dengan sabun sebelum masuk kampung, memakai masker selama berkeliling kampung, dan selalu menjaga jarak untuk mencegah penularan virus corona.

Dampak pandemi Covid-19 memang telah cukup signifikan mempengaruhi jumlah kunjungan wisatawan di Kampung Pelangi. Akibatnya, aktivitas ekonomi sejumlah warga di Kampung Pelangi dalam beberapa bulan terakhir ini mulai lesu karena sepi dari kunjungan wisatawan. Banyak warung yang mulai tutup. Meskipun demikian, masyarakat tidak patah semangat dan bahkan Kelompok sadar pariwisata (Pokdarwis) Kampung Pelangi sudah merencanakan untuk memperbarui cat dan bahkan bekerjasama dengan pemerintah daerah setempat akan membangun anak tangga berjumlah 999 untuk memudahkan pengunjung yang akan berwisata di Kampung Pelangi. Selain itu, masih banyak rencana kegiatan yang akan digelar untuk menarik lebih banyak pengunjung, meskipun semuanya masih menunggu berakhirnya pandemi Covid 19.

\section{Penutup}

\section{Simpulan}

Persepsi masyarakat setempat terhadap dampak pengembangan kawasan Kampung Pelangi sebagai daya tarik wisata di Kampung Wonosari Kota Semarang adalah menangggapi secara positif karena menurut anggapan mereka pengembangan Kampung Pelangi dapat membantu meningkatkan standar dan kualitas masyarakat 
setempat, mendorong berbagai kegiatan budaya seperti kerajinan dan seni di kampung Wonosari Semarang, serta membuat penampilan kampung Wonosari menjadi lebih baik.

Sebagian besar masyarakat memberikan dukungan terhadap pengembangan kawasan Kampung Pelangi sebagai daya tarik wisata di kampung Wonosari Semarang. Hal ini karena mayoritas masyarakat percaya bahwa manfaat pengembangan Kampung Pelangi lebih besar dibandingkan dengan biaya/kerugian yang ditimbulkan. Bahkan mereka sangat yakin bahwa pengembangan Kampung Pelangi lebih banyak memberikan dampak positif dari pada dampak negatifnya.

\section{Implikasi}

Implikasi praktis dari hasil penelitian ini adalah dengan menggali persepsi serta sikap masyarakat, pembuat dan perencana pariwisata dapat menilai sentimen lokal yang dapat digunakan sebagai bahan pertimbangkan atau masukan dalam menyusun perencanaan dan pengembangan Kampung Pelangi sebagai daya tarik wisata dimasa yang akan datang.

Dengan memunculkan pandangan dan persepsi masyarakat tentang pengembangan Kampung Pelangi, maka diharapkan dapat menemukan cara untuk mengurangi dan meminimalkan persepsi negatif terhadap dampak pengembangan Kampung Pelangi, terutama dampak lingkungan, sehingga dapat meningkatkan dukungan dan partisipasi masyarakat dalam program pengembangan Kampung Pelangi di masa mendatang.

\section{Keterbatasan Penelitian}

Penelitian yang telah dilakukan ini masih memiliki kelemahan dikarenakan adanya beberapa keterbatasan, antara lain karena penelitian ini hanya dilakukan pada lokasi penelitian yang terbatas dan jumlah sampel yang juga terbatas, yaitu sebagian dari masyarakat kampung Wonosari. Terlebih karena penelitian ini dilakukan di masa 
pandemi covid 19, sehingga pelaksanaan pengumpulan data menjadi kurang maksimal. Penelitian ini juga belum melakukan analisis pengaruh antara satu variabel dengan variabel yang lain.

\section{Agenda Penelitian Mendatang}

Penelitian mendatang dapat melakukan beberapa pengembangan dari penelitian ini, misalnya melakukan penelitian pada sampel yang lebih besar dan lebih intensif. Jika memungkinan, penelitian dilakukan pada seluruh populasi yang ada agar dapat memperoleh gambaran secara utuh. Selain itu penelitian yang akan datang dapat juga melakukan analisis pengaruh antar variabel.

\section{Daftar Pustaka}

Andriotis, K. 2004. "The Perceived Impact of Tourism Development by Cretan residents". Tourism and Hospitality: Planning \& Development, 1(2), 123-144.

Andriotis, K., \& Vaughan, R. D. 2003. “Urban Residents' Attitudes toward Tourism Development: The case of Crete". Journal of travel research, 42(2), 172-185.

Cahndralal, K., P., L. 2010. “Impacts of Tourism and Community Attitude towards Tourism: A Case Study in Sri Lanka". South Asian Journal of Tourism and Heritage, 3 (2), 41-49.

Chen, C.-F., \& Chen, P. C. 2010. “Resident Attitudes toward Heritage Tourism Development". Tourism Geographies, 12(4), 525-545.

Dyer, P., Gursoy, D., Sharma, B., \& Carter, J. 2007. “Structural Modelling of Resident Perceptions of Tourism and Associated Development on the Sunshine Coast", Australia. Tourism Management, 28(2), 409-422.

Eshliki, S. A., \& Kaboudi, M. 2012. “Community Perception of Tourism Impacts and Their Participation in Tourism Planning: A Case Study of Ramsar, Iran". Procedia-Social and Behavioral Sciences, 36, 333-341.

Faizun, M. 2009. “Dampak Perkembangan Kawasan Wisata Pantai Kartini Terhadap Masyarakat Setempat di Kabupaten Jepara". Doctoral dissertation. Program Pascasarjana Universitas Diponegoro. 
Ginting, Y. D. H., Tulusan, F., \& Pombengi, J. 2017. “Persepsi Masyarakat Tentang Pengembangan Pariwisata Pulau Lembeh (Studi di Kecamatan Lembeh Selatan Kota Bitung)". Jurnal Administrasi Publik, 3(046).

Głąbiński, Z., \& Duda, T. 2017. “The Local Community Perception of Tourism Development. The Case Study of Gryfino County-Western Pomerania, Poland". Bulletin of Geography.Socio-economic Series, 37(37), 7-23.

Gursoy, D. \& Denney, R. 2004. "Host Attitudes Toward Tourism, an Improved Structural Model". Annals of Tourism Research, 31(3): 495-516

Gursoy, D., Chi, C.G., \& Dyer, P. 2010. “Locals' Attitudes Toward Mass and Alternative Tourism: The Case of Sunshine Coast, Australia". Journal of Travel Research, 49(3), 381-394.

Hariyana, I Kadek \& Mahagangga, I.G.A.O. 2015. “Persepsi Masyarakat terhadap Pengembangan Kawasan Goa Peteng sebagai Daya Tarik Wisata di Desa Jimbaran Kuta Selatan Kabupaten Badung". Jurnal Destinasi Pariwisata. 3(1), 2434.

Hastuti, P., \& Ismayanti, D. 2018. “Analisis Dampak Wisata Kampung Pelangi Terhadap Peningkatan Pendapatan Masyarakat Sekitar (Pedagang) di Kelurahan Kemuning Kecamatan Banjarbaru Selatan". Jurnal Ilmiah Ekonomi Bisnis, 4(1): 29-35

Indonesia. 2009. Undang-Undang No. 10 Tahun 2009 tentang Kepariwisataan. Lembaran Negara RI Tahun, (4966).

Inskeep, E. 1991. Tourism Planning: an Integrated and Sustainable Development Approach. Van Nostrand Reinhold.

Ko, D.W., \& Stewart, W.P. 2002. “A Structural Equation Model of Residents' Attitudes for Tourism Development". Tourism Management, 23(5), 521-530.

Lee, T.H. 2013. “Influence Analysis of Community Resident Support for Sustainable Tourism Development". Tourism Management, 34, 37-46.

Mahmud, D. H., \& Si, M. 2011. Metode Penelitian Pendidikan, Bandung: CV. Pustaka Setia.

Manalu, B. E., Latifah, S., \& Patana, P. 2013. "Public Perception of Ecotourism Development in Huta Ginjang Village, Sianjur Mula-Mula Sub-District, Samosir". Peronema Forestry Science Journal, 2(1), 54-64.

McGehee, N.G., \& Andereck, K.L. 2004. "Factors Predicting Rural Residents' Support of Tourism". Journal of Travel Research, 43(2), 131-140.

Nunkoo, R., \& Ramkissoon, H. 2009. “Small Island Urban Tourism: a Residents' Perspective". Current Issues in Tourism, 13(1), 37-60. 
Nunkoo, R., \& Ramkissoon, H. 2011. “Developing a Community Support Model for Tourism". Annals of Tourism Research, 38(3), 964-988.

Pham, L. 2012. “Tourism Impacts and Support for Tourism Development in Ha Long Bay, Vietnam: An examination of Residents' Perceptions". Asia Social Science, 8(8).

Pitana, I Gde, Diarta, I Ketut Surya. 2009. Pengantar Ilmu Pariwisata (1). Yogyakarta: Andi.

Prayag, G., Hosany, S., Nunkoo, R., \& Alders, T. 2013. “London residents' support for the 2012 Olympic Games: The Mediating Effect of Overall Attitude". Tourism Management, 36, 629-640.

Robbins. S. P. 2003. Perilaku Organisasi, Jilid 2. Jakarta: PT. Indeks Kelompok Gramedia

Saygin, P., Acar, A., \& Gökkaya, S. 2015. "Residents' Attitudes and Perception Towards Tourism Development: The Case of Safranbolu. 1". Uluslararasi Türk Dünyasi Turizm Sempozyumu, 19-21.

Sharma, B., Dyer, P., Carter, J., \& Gursoy, D. 2008. “Exploring Residents' Perceptions of the Social Impacts of Tourism on the Sunshine Coast, Australia". International journal of hospitality $\mathcal{E}$ tourism administration, 9(3), 288311.

Snaith, T., \& Haley, A.J. 1999. "Residents' Opinion of Tourism Development in the Historic City of York, England". Tourism Management, 20(1), 595-603

Subhiksu, I. B. K., \& Utama, G. B. R. 2018. Daya Tarik Wisata Museum Sejarah dan Perkembangannya di Ubud Bali.Deepublish.

Sudarmayasa, I. W., \& Nala, I. W. L. 2019. “Dampak Keberadaan Sektor Pariwisata terhadap Peningkatan Faktor Sosial Ekonomi Masyarakat Kampung Tenun Samarinda di Kota Samarinda Kalimantan Timur". Jurnal Master Pariwisata (JUMPA), 5(2): 283-295.

Sugiyono, P. 2011. Metodologi penelitian kuantitatif kualitatif dan RED. Bandung: Alfabeta.

Tibuludji, U. S., Mahendra, M. S., \& Adhika, I. M. 2017. “Dampak Perkembangan Pariwisata Terhadap Kehidupan Masyarakat Pesisir Kelapa Lima, Kupang". Jurnal Master Pariwisata (JUMPA), 4 (1): 91-104.

Toha. M. 2003. Perilaku Oganisasi Konsep Dasar dan Aplikasinya. Jakarta: Raja Grafindo Persada.

Utama, R., Bagus, I. G., Dhyana, U., \& Bali, P. 2017. “Kajian Pariwisata dari Perspektif Ekonomi". Makal.Semin.Univ. Tabanan, Januari.

Wulandari, S. S., \& Luthfi, A. 2019. "Hiperealitas Kampung Pelangi Semarang". Solidarity: Journal of Education, Society and Culture, 7(2), 462-479. 
Wuri, J., Hardanti, Y. R., \& Harnoto, L. B. 2015. “Dampak Keberadaan Kampung Wisata terhadap Kehidupan Ekonomi dan Sosial Masyarakat".Jurnal Penelitian, 18(2): 143-156.

\section{Profil Penulis}

Aurilia Triani Aryaningtyas, S.E., M.M. adalah dosen di Sekolah Tinggi Ilmu Ekonomi Pariwisata Indonesia (STIEPARI) Semarang pada Program Studi S1 Pariwisata. Menyelesaikan Program Studi Magister Manajemen Universitas Kristen Satya Wacana Salatiga pada tahun 2012. Bidang keahlian yang diampu adalah Manajemen Sumber Daya Manusia, Statistik, dan Ekonomi Pariwisata.

Dra. Renny Aprilliyani, M.M. adalah dosen di Sekolah Tinggi Ilmu Ekonomi Pariwisata Indonesia (STIEPARI) Semarang pada Program Studi S1 Manajemen. Menyelesaikan Program Studi Magister Manajemen Universitas Diponegoro Semarang pada tahun 2001. Bidang keahlian yang diampu adalah Manajemen SDM, dan Manajemen Pariwisata.

Drs. Hartoyo Soehari, MPA., Ph.D. adalah dosen di Sekolah Tinggi Ilmu Ekonomi Pariwisata Indonesia (STIEPARI) Semarang pada Program Studi S2 Manajemen. Menyelesaikan Program S2 - Public Administration, Pittsburg University dan Program S3 - Social Science Education, Florida University. Bidang keahlian yang diampu adalah Manajemen Pendidikan. 